\title{
Effect of agronomic manipulations on growth, yield attributes and seed cotton yield of American cotton under semi-arid conditions
}

\author{
KULVIR SINGH \\ Regional Research Station (P.A.U.), FARIDKOT (PUNJAB) INDIA(Email : kulvir@pau.edu)
}

\begin{abstract}
Field studies were conducted at Punjab Agricultural University, Regional Station, Faridkot during Kharif 2012 to evaluate the performance of three hirsutum genotypes (Bihani251, CSH3129 and LH2076) in main, two plant geometries $(67.5 \times 60 \mathrm{~cm}$ and $67.5 \times 75 \mathrm{~cm})$ in sub and three nitrogen levels $(56,75$ and $94 \mathrm{~kg} \mathrm{~N} / \mathrm{ha})$ in sub plots of Split Plot Design replicated thrice. None of the tested new genotypes i.e. Bihani 251 (2074.5 kg/ha) and CSH3129 (1969.6 kg/ha) could out yield check variety LH2076 (2281.1 kg/ha). Among plant geometries, $67.5 \times 60 \mathrm{~cm}$ recorded significantly better SCY $(2258.7 \mathrm{~kg} / \mathrm{ha})$ as compared to $67.5 \times 75 \mathrm{~cm}$ spacing $(1958.1 \mathrm{~kg} / \mathrm{ha})$ primarily owing to higher plant population though bolls per plant were significantly superior under wider (44.6) over the narrow (40.9) plant geometry. Seed cotton yield also differed non-significantly for nitrogen levels. Though cost of cultivation increased statistically with each increase of nutrient levels, but gross as well as net returns and B:C ratio could not improve significantly indicating $56 \mathrm{~kg} \mathrm{~N}$ to be optimum level under semi-arid conditions.
\end{abstract}

Key Words : Agronomic manipulations, Genotypes, Plant geometry, Seed cotton yield

View Point Article : Singh, Kulvir (2015). Effect of agronomic manipulations on growth, yield attributes and seed cotton yield of American cotton under semi-arid conditions. Internat. J. agric. Sci., 11 (1): 134-137.

Article History : Received : 07.07.2014; Revised : 23.11.2014; Accepted : 09.12.2014 